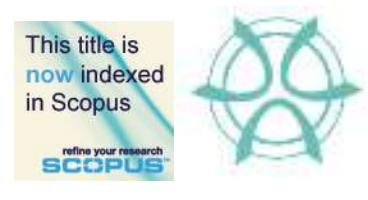

PLANNING MALAYSIA:

Journal of the Malaysian Institute of Planners

VOLUME 18 ISSUE 4 (2020), Page 220 - 238

\title{
LAND USE DEVELOPMENT AND RIDERSHIP AT KELANA JAYA LRT LINE, MALAYSIA
}

\author{
Jamalunlaili Abdullah ${ }^{1}$, Kushairi Abdul Rashid ${ }^{2}$, Muhammad Ikram Baharom \\ Shah $^{3}$, Oliver Ling Hoon Leh ${ }^{4}$, Rohayu Abdul Majid ${ }^{5}$, Rohana Ngah \\ ${ }^{1-5}$ Southeast Asia Built Environment Research Centre (SEABERC) \\ Faculty of Architecture, Planning and Surveying, \\ UNIVERSITI TEKNOLOGI MARA (UITM) \\ ${ }^{6}$ Malaysian Academy of SME and Entrepreneurship Development (MASMED) \\ UNIVERSITI TEKNOLOGI MARA (UITM)
}

\begin{abstract}
Urbanisation has led to increased traffic use and congestion in various cities around the world. Various policies and strategies have been implemented to address the issue. One of the most popular strategies is the development of transit system, including mass rapid transit (MRT) and light rapid transit (LRT). To ensure the success of the transit system, the concept of Transit Oriented Development, in which land uses around the stations that are developed for urban development has been implemented. This paper evaluates a possible relationship between land uses around the station and ridership in selected stations along the Kelana Jaya LRT line in the Kuala Lumpur metropolitan area, Malaysia. The land uses around the station were calculated using Land Use and Public Transport Accessibility Index (LUPTAI). The research did not conclusively find a strong relationship between LUPTAI and ridership. This was perhaps due to the fact that almost all stations had been developed for urban land uses, such as commercial, residential and public facilities, thus giving all stations almost the same index figures. It is hope that a more detailed index that accounts for type and mixture of development on land, as well as the density for residential areas would probably give a better index result, as well as perhaps a stronger relationship with ridership figures.
\end{abstract}

Keywords: Transit Oriented Development, land uses, LUPTAI, transit ridership

\footnotetext{
${ }^{1}$ Jamalunlaili Abdullah, professor of Town Panning, UiTM. Email: jama1858@uitm.edu.my
} 
PLANNING MALAYSIA

Journal of the Malaysia Institute of Planners (2020)

\section{INTRODUCTION}

Urbanisation has led to increased traffic use and congestion in cities around the world. Automobile dependency, especially in relation to urban sprawl has led to gridlocks and increased greenhouse emissions, resulting in negative environmental, social and economic impacts to nations. Various policies and strategies have been implemented to address the issue of automobile dependency and the resulting traffic congestions. One of the most popular strategies is the development of transit system, including the mass rapid transit (MRT) and light rapid transit (LRT). LRT was first implemented at Metropolitan Kuala Lumpur, Malaysia in 1998 and has since expanded to include MRT and covers newer areas within the Klang Valley. The transit system has been successful in that LRT3 and MRT2 are currently being constructed at the metropolitan area.

The literature has argued that many factors do influence the ridership figures of the transit system. These factors, include socio-economic factors, such as the population served by the system, the fare and the incentives provided to the riders. Other factors encompass physical aspects, such as the areas served which are the types of land use and intensity of use. The physical aspect theory contends that the land uses and intensity of use found around the station will affect the number of riders using the transit system. Commercial, residential and public facilities land uses are likely to attract more transit riders as compared to other land uses, such as forestry and open spaces. Thus, the former categories are encouraged to be built around the LRT station, especially in stations designated as Transit Oriented Development (TOD) station, in which a greater intensity of use is also allowed. Sohoni et al. (2016) argued that TOD is a viable tool for sustainable development of cities, particularly in relation to TOD.

TOD is a land use solution that focuses in enhancing accessibility, as well as also encouraging compact, high density and mixed-use development within an easy walk of a transit station. Transit Oriented Development (TOD) is now becoming a popular solution to optimise the use of land and to tackle urban transportation issues. A typical TOD neighbourhood has a diameter of a quarter to half mile (400 to 800 metres) which represents pedestrian scale distances (five to ten minutes' walk). Kuala Lumpur City Hall and surrounding municipalities have identified Transit Planning Zone (TPZ) to areas within 400 metres of a transit station in order to encourage more TOD development at Kuala Lumpur metropolitan.

This paper discusses the analysis of land uses within selected ten stations along Kelana Jaya LRT line within Petaling Jaya City Council and Subang Jaya Municipal Council areas. This study applies Land Use and Public Transportation Accessibility Index (LUPTAI), as well as observation method to analyse the relationship between land uses and LRT ridership. These LUPTAI figures are then compared to the ridership data of the stations provided by 
Abdullah, J., Abdul Rashid, K., Baharom Shah M.I., Oliver Ling Hoon Leh, Abdul Majid, R., Ngah, R.

Land Use Development and Ridership at Kelana Jaya LRT Line, Malaysia

Prasarana Malaysia. The relationship between these two variables are then ascertained through a comparative analysis.

\section{LITERATURE REVIEW}

This section reviews literature related to Transit Oriented Development (TOD), transit ridership, as well as LUPTAI. It analyses the concept and evolution of TOD, factors influencing transit ridership, as well as the LUPTAI technique since all three variables are closely related and influence one another. It also seeks to ascertain if previous studies have proven that there is a relationship between LUPTAI and ridership of transit system.

\section{Transit Oriented Development}

The provision of train-based mass transportation systems, also known as transit systems, is an effective way to tackle the challenges faced by cities, such as traffic jams, air pollution, greenhouse gas emissions, and other social problems which affect the quality of city life (Suzuki et al., 2015) as it alters the use of private vehicles. While many factors affect the performance of the transit system, physical development surrounding the transit station has been thought to influence the ridership figures. Effective integration of land uses surrounding the transit stations can help to spur ridership of the transit system.

TOD is a developed area that focuses on transit as its basic principle is a development of which is expected to fulfill the purpose of sustainability both in transport and urban planning (Mohammed Ali Berawi et al., 2020). TOD devises urban development plans based on public transportation systems to enhance the sustainability of MRT systems, land use efficiency and traffic operation effectiveness. Several studies have shown a connection between transit service, ridership and improvements in traffic safety (Litman, 2016).

Besides that, rather than separately considering transit systems and relevant land uses, a good planning strategy should integrate both aspects into the TOD aspect of the urban spatial structure planning (Ding et al., 2017). TOD provides a compact and mixed-use with transit-oriented communities that has a convenient access to employment areas and facilities. TOD also focuses on urban growth around transit facilities and leverages on transit investments to help produce substantial benefits, such as walkable communities, an improved accessibility to jobs and economic opportunities, a reduced motor traffic congestion, less air pollution and lower greenhouse gas emissions. (Buang, 2018). Theoretically, TOD can enhance accessibility by providing a relatively high level of transportation connections and high-density, mixed-use, cycling- and pedestrian-friendly land use around transit stations (Guowei \& Pfeffer, 2020). TOD is a potential solution to support the growth of urban population and to make the transit system more attractive. This is because TOD is primarily expected to 
help in reducing dependability on private vehicles, as well as encouraging public transportation and walking as a lifestyle in a city (Litman, 2018).

TOD has been applied in several countries, such as Singapore, China, Australia, India, and United States (Arina Rahmat et al., 2016). In Malaysia, TOD increasingly becomes a priority for developers and property companies to lead urban planning towards creating a quality, prosperous and sustainable living environment. There are some policies and incentives related to TOD are contained in $10^{\text {th }}$ Malaysian Plan (Chapter 6), National Physical Plan 3 (NPP3), National Urbanisation Policies 2 (NUP2), as well as Draft Planning and Design Guidelines for Compact and Livable Development to encourage the use of public transportation, walking and cycling as an alternative to the main modes in the development.

The emphasis on TOD is also clearly outlined in the state structure plans and local plans, such as the Selangor Structure Plan 2020, and Kuala Lumpur City Plan 2020, as well as in regional plans, such as Iskandar Region's Comprehensive Development Plan (CDP) (Gomez et al., 2019). Some local authorities do provide incentives for developers to build within 400 metres of the transit station. This is usually done through higher than normal plot ratio for commercial development and higher density for residential development.

\section{Ridership}

Pertaining to TOD, the relationship between the built environment and transit ridership attracts lots of attention (Choi et al., 2012). Many governments use land use policies to influence travel demand (Singh et al., 2018). The land use policies' primary benefit is to increase transit ridership which is critical for a sustainable transit system. To understand the correlation of transit ridership and to predict transit demand, many scholars investigated the relationship between the stationarea built environment and transit ridership (Liu et al., 2018). The coefficients of built environment variables are found to vary across space, indicating that the influences of residential locations on commuting behaviour vary by the type of employment centre (Hu et al., 2018).

Public transportation plays an important role in fulfilling transportation needs as there are many external and internal factors that affect public transportation demands. External factors are associated with socioeconomic developments, which are not subjected to controls, such as income, car ownership, population, employment, and other household characteristics. On the other hand, the internal factors are characteristics of the public transportation system and are subjected to policy decisions including public transportation fares, trip length, travel time, and service levels (Al-Sahili et al., 2003). Table 1 lists factors that influence transit ridership. 
Abdullah, J., Abdul Rashid, K., Baharom Shah M.I., Oliver Ling Hoon Leh, Abdul Majid, R., Ngah, R.

Land Use Development and Ridership at Kelana Jaya LRT Line, Malaysia

Table 1: Factors that influence ridership

\begin{tabular}{lc}
\hline Factors That Influence Ridership & $\begin{array}{l}\text { Author or } \\
\text { Researcher }\end{array}$ \\
\hline $\begin{array}{l}\text { Commercial and governmental land uses, bus connectivity and transfer } \\
\text { stations are all associated with station attraction ridership during morning } \\
\text { peak hours. }\end{array}$ & Chan and Miranda- \\
\hline $\begin{array}{l}\text { The influencing factors on Taipei metro station ridership cover four } \\
\text { dimensions: land uses, social economy, accessibility, and network structure. }\end{array}$ & Yuxin et al. (2018) \\
\hline $\begin{array}{l}\text { Transit planners and policy-makers need to know the influences of changes } \\
\text { in transit service and the built environment on transit ridership. It is }\end{array}$ & Chu (2004) \\
important to know these influences for several reasons. & \\
\hline $\begin{array}{l}\text { Probing into the issue of last-mile solutions in Singapore, Tay (2012) found } \\
\text { that porosity, which is a pedestrian connectivity measure, is significantly and } \\
\text { positively associated with a higher station ridership. }\end{array}$ & Tay (2012) \\
$\begin{array}{l}\text { TOD is intended to increase transit ridership and walking but to decrease } \\
\text { biking, and shares of automobile trips. The design and mixed-use features of } \\
\text { TOD may reduce both work and non-work automobile trips. }\end{array}$ & Lund et al. (2004) \\
\hline
\end{tabular}

Source: various authors as listed

\section{Land Use and Public Transport Accessibility Index (LUPTAI)}

Land Use and Public Transport Accessibility Index (LUPTAI) is a decisionaiding tool to enable local and state governments to optimise land uses and transportation integration. LUPTAI seeks to measure how easy it is to access common destinations, such as health, education, retail, banking, and employment centres by walking and/or public transportation (Pitot et al., 2006). Accessibility indexing is important in evaluating existing land use patterns and transportation service, predicting travel demands and allocating transportation investments (Tan et al., 2007). LUPTAI reflects the ease of reaching needed or desired activities and thus, reflects the characteristics of both land use system and the transportation system (Handy \& Clifton, 2001; Wu \& Hine, 2003).

Accessibility refers to the ease, in which people can access important destinations using public transportation service. LUPTAI is developed by Queensland's Department of Transportation and Main Roads (TMR) to estimate the expected travel time from origin nodes to important destinations (Bertolaccini et al., 2018). It was developed in 2006 to measure how easy it was to access common destinations, such as residential, health, education, commercial, and offices by walking or using public transportation. LUPTAI is an origin-based accessibility model. This information relates to the land use destinations (LUDs), the road or pedestrian network and the public transportation network. The fourcolour scale shows the levels of accessibility for an area, highlighting areas of high, moderate, low, and weak accessibility. Therefore, the land uses and distance 
from the transit stations are the main determining factors for LUPTAI (Tan et al., 2006).

\section{METHODOLOGY}

The data collection method in this study area consisted of primary and secondary data. The primary data were observations of the land uses and built up area within 500 metres of ten selected LRT stations along the Kelana Jaya LRT line. The secondary data were obtained from the land use plan provided by Petaling Jaya Municipal Council (MBPJ) and Subang Jaya Municipal Council (MPSJ), as well as ridership data provided by Prasarana Malaysia. LUPTAI was calculated by measuring the distance from the station to the urban development within the 500metre parameter. The distance was divided into four (4) categories ranging from weak to high based on distances as displayed in Table 2 .

Table 2: Ranking score of LUPTAI index

\begin{tabular}{ccccc}
\hline RANKING & W & L & M & H \\
\hline LEVEL & WEAK & LOW & MODERATE & HIGH \\
DISTANCE & $300-500 \mathrm{M}$ & $200-300 \mathrm{M}$ & $100-200 \mathrm{M}$ & $100 \mathrm{M}$ \\
SCORE & 0.1 & 0.2 & 0.3 & 0.4 \\
\hline
\end{tabular}

i. High (Green in Table 3.1) - for land uses within a 100-metre radius from the station which has the strongest impact on ridership for that station

ii. Moderate (Yellow in Table 3.1) - for land uses between 100 to 200-metre radius from the LRT station which is likely to have a moderate impact on ridership

iii. Low (Orange in Table 3.1) - for land uses between 200 to 300-metre radius, in which people start to calculate, whether they should walk on a sunny day or using another mode of transportation.

iv. Weak (Red in Table 3.1) - For land use between 300 to 500-metre radius which is likely to have a weak impact on LRT ridership among the four groups due to the distance. 


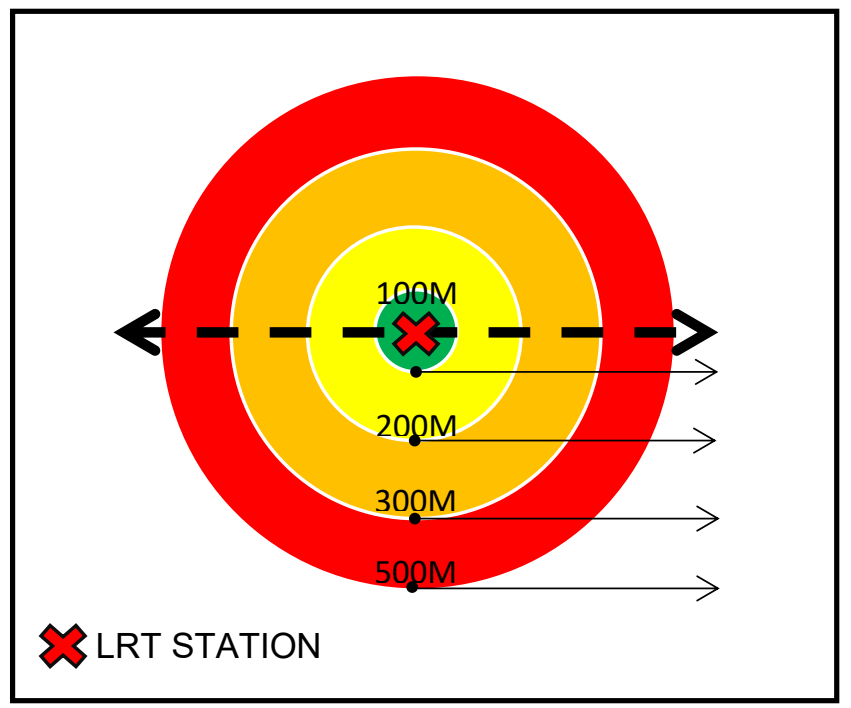

Figure 1: LUPTAI measurement distance

The land use survey confirmed the secondary data of land uses provided by MBPJ and MBSA around the ten selected stations. The land use pattern consisted of commercial, residential and public facilities. One of the key outputs of LUPTAI was a composite index that provided a measure of the level of accessibility for all the land use destinations considered within the analysis. The composite index was based on a rudimentary weighting that residential area, commercial and public facilities land used as an equal value of influence on the overall composite index. The LUPTAI measured the distance of these land uses to the station and contributed to a higher value to land uses closest to the station.

\section{STUDY AREA}

Klang Valley currently has a six-line rapid rail transit network. while LRT 3 and MRT Sungai Buluh Serdang Putrajaya (SSP) are currently constructed. The rail networks within the Klang Valley are KTMB Commuter, KLIA Transit or Express, Sri Petaling LRT line, Kelana Jaya LRT line, Kuala Lumpur (KL) monorail, and the newly operated MRT Sungai Buluh-Kajang line. Kelana Jaya LRT line is the fifth rail transit line and the first fully-automated and driverless rail system in the Klang Valley area that forms a part of Klang Valley Integrated Transit System. Kelana Jaya LRT line runs from Putra Heights LRT through Kelana Jaya to Gombak, comprises 46.4 kilometres of grade-separated tracks with 37 stations. This shows that Kelana Jaya LRT line is one of the most established rail lines at Klang Valley which contributes the highest ridership among all the lines, serving Subang Jaya, Petaling Jaya and Kuala Lumpur. This paper evaluates the selected ten stations, namely Lembah Subang (KJ25), Ara 
Damansara (KJ26), Glenmarie (KJ27), Subang Jaya (KJ28), SS15 (KJ29), USJ7 (KJ31), Taipan (KJ32), Wawasan (KJ33), USJ21(KJ34), and Alam Megah (KJ35) which are located within the MBPJ and MPSJ jurisdictions.

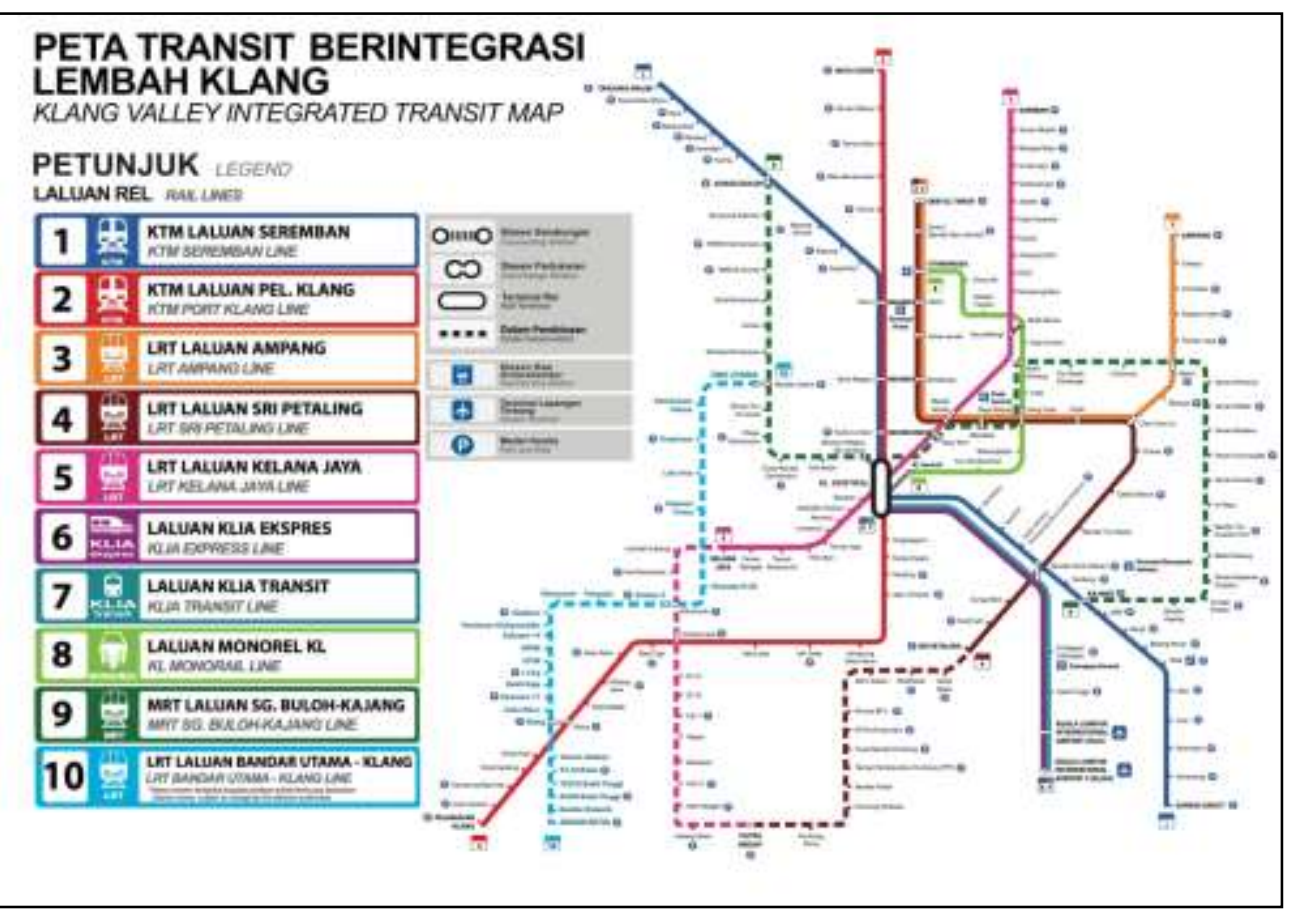

Figure 2: The rail network at Klang Valley, Malaysia

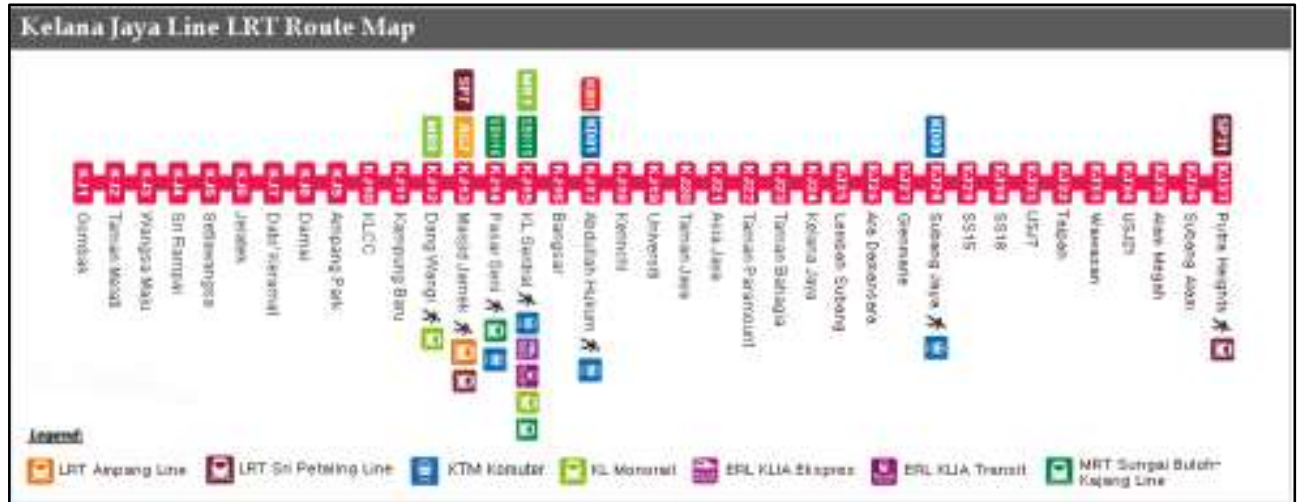

Figure 3: Kelana Jaya LRT line route map 
Abdullah, J., Abdul Rashid, K., Baharom Shah M.I., Oliver Ling Hoon Leh, Abdul Majid, R., Ngah, R.

Land Use Development and Ridership at Kelana Jaya LRT Line, Malaysia

\section{RESULTS AND FINDINGS}

\section{Land uses}

The result of the land use analysis in Table 3 illustrated that almost all land-use patterns within 500 metres of the LRT stations were commercial and residential areas. Some, such as Taipan, Wawasan, and USJ21 stations were dominated by residential land uses, while a few others were a mixture of residential and commercial uses. This land-use data distribution was used to calculate LUPTAI for each station. Since the study area was a mature transit line, almost all lands around the stations had been developed with mostly commercial or residential development.

Table 3: Land use distribution around LRT stations

\begin{tabular}{|c|c|c|c|c|c|c|c|}
\hline \multirow{3}{*}{$\begin{array}{c}\text { LRT } \\
\text { STATION }\end{array}$} & \multicolumn{6}{|c|}{ LAND USE } & \multirow{3}{*}{ Total \% } \\
\hline & \multicolumn{2}{|c|}{ Residential } & \multicolumn{2}{|c|}{ Commercial } & \multicolumn{2}{|c|}{ Public Facilities } & \\
\hline & Area $(\mathrm{Km})$ & $\%$ & $\operatorname{Area}(\mathrm{Km})$ & $\%$ & $\operatorname{Area}(\mathrm{Km})$ & $\%$ & \\
\hline $\begin{array}{l}\text { LEMBAH } \\
\text { SUBANG }\end{array}$ & 0.462 & 55.66 & 0.283 & 34.10 & 0.085 & 10.24 & 100 \\
\hline $\begin{array}{l}\text { ARA } \\
\text { DAMANSARA }\end{array}$ & 0.305 & 35.46 & 0.340 & 39.54 & 0.215 & 25 & 100 \\
\hline GLENMARIE & 0.255 & 49.04 & 0.220 & 42.31 & 0.045 & 8.65 & 100 \\
\hline $\begin{array}{l}\text { SUBANG } \\
\text { JAYA }\end{array}$ & 0.270 & 51.92 & 0.220 & 42.31 & 0.030 & 5.77 & 100 \\
\hline SS15 & 0.510 & 65.81 & 0.200 & 25.80 & 0.065 & 8.39 & 100 \\
\hline USJ 7 & 0.330 & 52.80 & 0.240 & 38.40 & 0.055 & 8.80 & 100 \\
\hline TAIPAN & 0.420 & 70.59 & 0.110 & 18.49 & 0.065 & 10.92 & 100 \\
\hline WAWASAN & 0.600 & 80.00 & 0.080 & 10.67 & 0.070 & 9.33 & 100 \\
\hline USJ 21 & 0.670 & 84.28 & 0.030 & 3.77 & 0.095 & 11.95 & 100 \\
\hline $\begin{array}{l}\text { ALAM } \\
\text { MEGAH }\end{array}$ & 0.310 & 62 & 0.045 & 9 & 0.145 & 29 & 100 \\
\hline
\end{tabular}




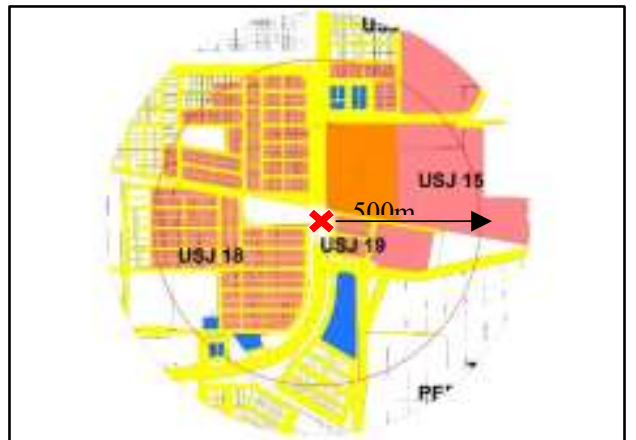

Figure 4: Land use distribution at Wawasan LRT station High LUPTAI index 24.34 and low ridership 586,272

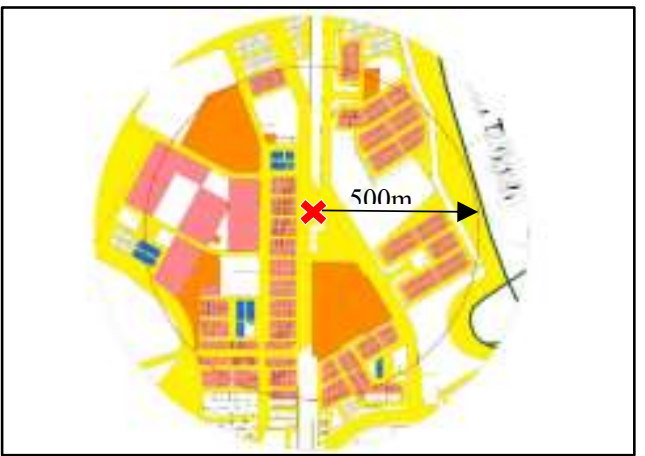

Figure 6: Land use distribution at Alam Megah LRT station LUPTAI index 20.24 and 501,382 total ridership

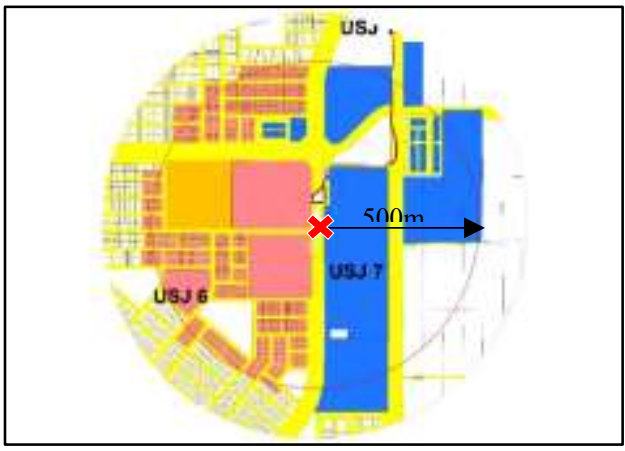

Figure 5: Land use distribution at USJ7 LRT station Low LUPTAI index 18.37 and high ridership 2,051,381

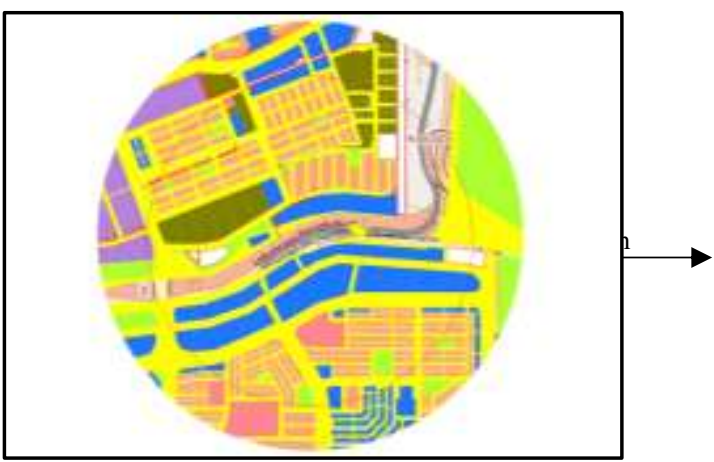

Figure 7: Land use distribution at Subang Jaya LRT station LUPTAI index 19.55 and $1,949,828$ total ridership

\section{LAND USES AND PUBLIC TRANSPORTATION ACCESSIBILITY INDEX (LUPTAI)}

The land-use data comprising of residential, commercial and public facilities land uses were calculated based on the distance of the uses from the stations (see Table 3 ). Hence, stations that had most of the lands closest to them were developed as commercial, residential or public facilities. These stations also tended to have a higher LUPTAI as compared to areas around stations that had not been developed yet. The results demonstrated that LUPTAI for all stations did not differ much from one another. Seven out of ten stations had LUPTAI readings of 19 and 20 (see Table 4). This was perhaps because almost all areas around the stations had been developed since they were in relatively mature urban areas. Consequently, 
Abdullah, J., Abdul Rashid, K., Baharom Shah M.I., Oliver Ling Hoon Leh, Abdul Majid, R., Ngah, R. Land Use Development and Ridership at Kelana Jaya LRT Line, Malaysia

not much variation was shown in terms of LUPTAI among the stations as most stations seemed to have commercial or residential uses. Wawasan station had the highest LUPTAI score of 24.3 since it had a larger percentage of urban land use within 100 metres from the stations as exhibited by the green colour in Table 4 and Figure 8 . Figure 8 shows the distribution of land uses by group ranking within the 500-metre radius of the ten selected stations.

Table 4: LUPTAI index of TOD Station Kelana Jaya Line

\begin{tabular}{|c|c|c|c|c|c|c|}
\hline Station & LRT Line & Weak & Low & Moderate & High & Total \\
\hline & Score & 0.1 & 0.2 & 0.3 & 0.4 & Index \\
\hline $\begin{array}{l}\text { LEMBAH } \\
\text { SUBANG }\end{array}$ & $\mathrm{KJ} 25$ & 18.65 & 61.12 & 12.76 & 7.47 & 20.88 \\
\hline $\begin{array}{c}\text { ARA } \\
\text { DAMANSARA }\end{array}$ & $\mathrm{KJ} 26$ & 40 & 20.78 & 30.4 & 8.82 & 20.79 \\
\hline GLENMARIE & $\mathrm{KJ} 27$ & 37.48 & 35.33 & 24.16 & 3.03 & 19.19 \\
\hline SUBANG JAYA & $\mathrm{KJ} 28$ & 29.26 & 53.68 & 9.15 & 7.91 & 19.55 \\
\hline SS15 & $\mathrm{KJ} 29$ & 16.94 & 60.69 & 17.70 & 4.64 & 20.98 \\
\hline USJ7 & KJ31 & 37.75 & 45.39 & 12.06 & 4.8 & 18.37 \\
\hline TAIPAN & KJ32 & 31.18 & 46.62 & 19.82 & 2.38 & 19.32 \\
\hline WAWASAN & $\mathrm{KJ} 33$ & 28.57 & 41.47 & 23.68 & 15.27 & 24.34 \\
\hline USJ21 & KJ34 & 16.96 & 51.92 & 22.77 & 8.01 & 22.1 \\
\hline ALAM MEGAH & KJ35 & 29.28 & 44.74 & 20.43 & 5.67 & 20.24 \\
\hline
\end{tabular}

Source: Own survey 


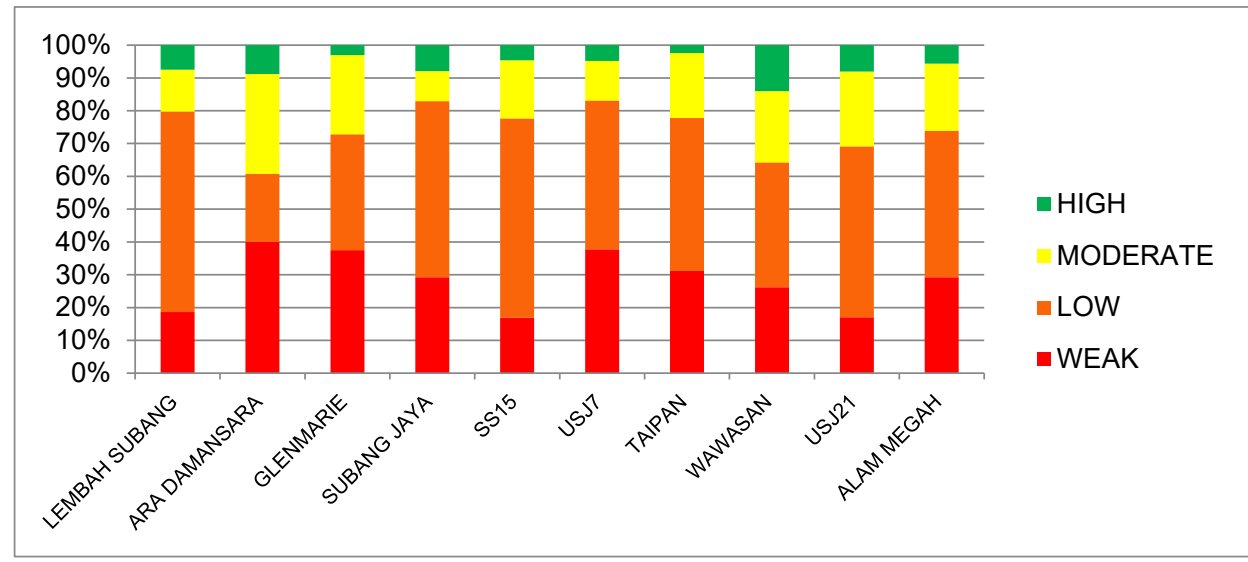

Figure 8: Distribution of urban land use around LRT stations

$$
\text { Source: Own survey }
$$

\section{Ridership}

Data of ridership for 2019 were provided by Prasarana based on the number of passengers entering and leaving the ten selected stations (see Table 5). There was a significant variation of total ridership among the stations with the lowest at Taipan (501,382 passengers) of only one-fourth of total ridership at USJ7 $(2,051,358$ passengers). Generally, stations with dominant commercial and mixed commercial and residential use were observed to have a much higher ridership as compared to stations surrounded mostly by residential or facilities land use. All stations with commercial land uses would have at least 1.5 million passengers as compared to stations with residential base that had ridership between half a million to 1.2 million. The highest figure was exhibited by USJ 7 stations which had a mixture of commercial and residential uses. This was perhaps because the commercial areas tended to attract diverse people, especially if they were also seeking for a place in employment. They also seemed to attract commuters throughout the day, unlike residential areas which seemed to peak in the morning and afternoon rush hours.

Table 5: Number of ridership year 2019

\begin{tabular}{cccc}
\hline STATION NAME & STATION NO & DOMINANT LAND USE & $\begin{array}{c}\text { TOTAL } \\
\text { RIDERSHIP 2019 }\end{array}$ \\
\hline LEMBAH SUBANG & KJ 25 & RESIDENTIAL BASE & $1,224,799$ \\
\hline ARA DAMANSARA & KJ 26 & COMMERCIAL BASE & $1,473,422$ \\
\hline GLENMARIE & KJ 27 & COMMERCIAL BASE & $1,446,392$ \\
\hline SUBANG JAYA & KJ 28 & COMMERCIAL BASE & $1,949,828$ \\
\hline SS15 & KJ 29 & COMMERCIAL AND RESIDENTIAL BASE & $1,476,560$ \\
\hline USJ7 & KJ 31 & COMMERCIAL AND RESIDENTIAL BASE & $2,051,381$ \\
\hline TAIPAN & KJ 32 & RESIDENTIAL BASE & 845,917 \\
\hline
\end{tabular}


Abdullah, J., Abdul Rashid, K., Baharom Shah M.I., Oliver Ling Hoon Leh, Abdul Majid, R., Ngah, R.

Land Use Development and Ridership at Kelana Jaya LRT Line, Malaysia

\begin{tabular}{|c|c|c|c|}
\hline WAWASAN & KJ 33 & RESIDENTIAL BASE & 586,272 \\
\hline USJ21 & KJ 34 & RESIDENTIAL BASE & 555,394 \\
\hline ALAM MEGAH & KJ 35 & FACILITIES BASE & 501,382 \\
\hline \multicolumn{3}{|c|}{ TOTAL } & $12,111,347$ \\
\hline
\end{tabular}

Source: Prasarana Malaysia (2020)

\section{Relationship between LUPTAI and Ridership}

Table 6 and Figure 8 present a simple relationship between LUPTAI and ridership. It was expected that a station with a high LUPTAI was likely to generate a high ridership figure. However, as could be seen in Figure 8, there was no a close relationship between LUPTAI and total ridership. Stations with higher LUPTAI figures, such as Wawasan, USJ 21 and Alam Megah were reported to have lower numbers of ridership as compared to stations with slightly lower LUPTAI, such as USJ7, Subang Jaya, SS15, and Ara Damansara. USJ7 had a very high ridership since the station was connected to a mixture of residential and commercial area which also had many facilities resulting with higher ridership figures.

Table 6: Total ridership and station LUPTAI index

\begin{tabular}{|c|c|c|c|c|}
\hline STATION NAME & STATION NO & DOMINANT LAND USE & $\begin{array}{c}\text { TOTAL } \\
\text { RIDERSHIP } 2019\end{array}$ & $\begin{array}{l}\text { LUPTAI } \\
\text { INDEX }\end{array}$ \\
\hline $\begin{array}{l}\text { LEMBAH } \\
\text { SUBANG }\end{array}$ & KJ 25 & RESIDENTIAL BASE & $1,224,799$ & 20.88 \\
\hline $\begin{array}{c}\text { ARA } \\
\text { DAMANSARA }\end{array}$ & KJ 26 & COMMERCIAL BASE & $1,473,422$ & 20.79 \\
\hline GLENMARIE & KJ 27 & COMMERCIAL BASE & $1,446,392$ & 19.19 \\
\hline SUBANG JAYA & KJ 28 & COMMERCIAL BASE & $1,949,828$ & 19.55 \\
\hline SS15 & KJ 29 & $\begin{array}{l}\text { COMMERCIAL AND RESIDENTIAL } \\
\text { BASE }\end{array}$ & $1,476,560$ & 20.98 \\
\hline USJ7 & KJ 31 & $\begin{array}{l}\text { COMMERCIAL AND RESIDENTIAL } \\
\text { BASE }\end{array}$ & $2,051,381$ & 18.37 \\
\hline TAIPAN & KJ 32 & RESIDENTIAL BASE & 845,917 & 19.32 \\
\hline WAWASAN & KJ 33 & RESIDENTIAL BASE & 586,272 & 24.34 \\
\hline USJ21 & KJ 34 & RESIDENTIAL BASE & 555,394 & 22.1 \\
\hline ALAM MEGAH & KJ 35 & FACILITIES BASE & 501,382 & 20.24 \\
\hline \multicolumn{3}{|c|}{ TOTAL } & $12,111,347$ & \\
\hline
\end{tabular}




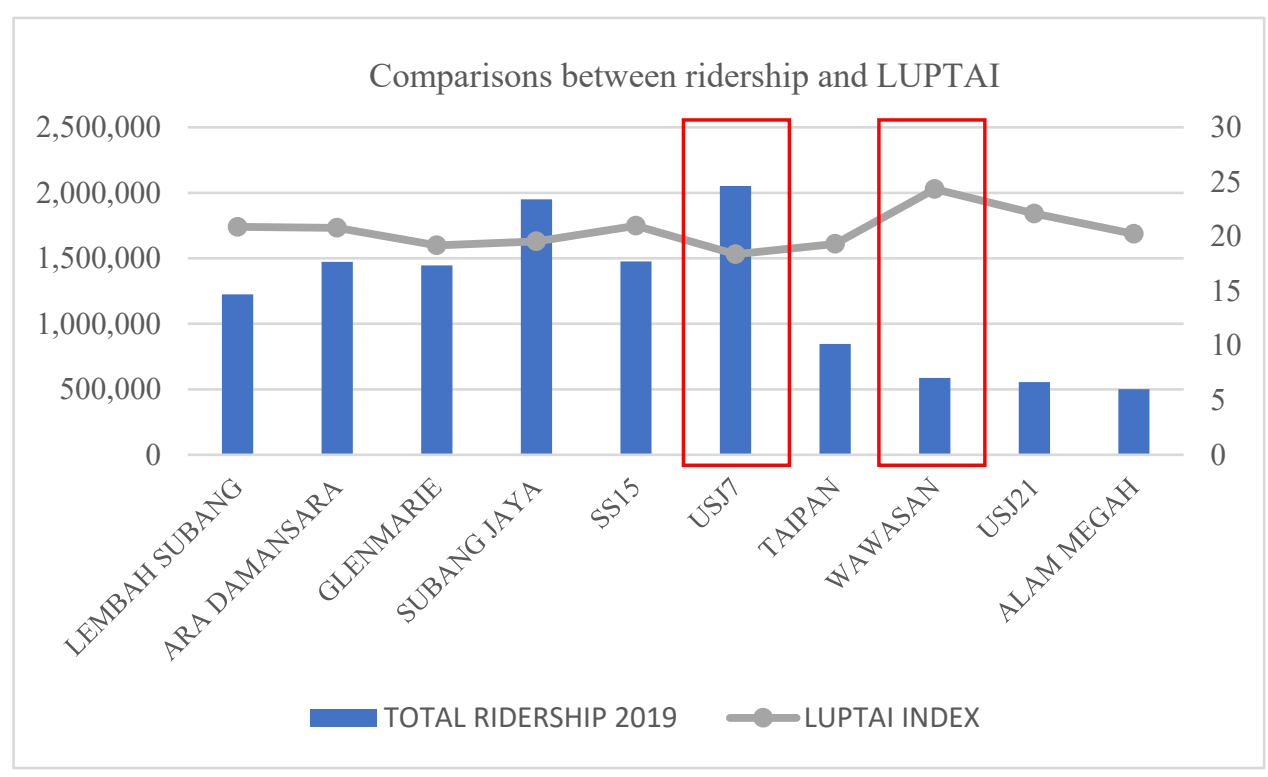

Figure 8: Comparisons between ridership and LUPTAI

Further analysis through observations of selected sites revealed that simple LUPTAI calculations based only on distance of urban land uses (commercial, residential and public facilities) from LRT stations were inadequate to explain the variation in ridership. A closer look around Wawasan station showed that despite its highest LUPTAI figures, the development around the station that consisted of schools and terrace houses was shown to generate low ridership. The proximity of these school and houses had given Wawasan station a high LUPTAI figure. Although there was a USJ City mall nearby, its location was about 300 metres from the station, reducing its effectiveness in attracting more ridership. 
Abdullah, J., Abdul Rashid, K., Baharom Shah M.I., Oliver Ling Hoon Leh, Abdul Majid, R., Ngah, R.

Land Use Development and Ridership at Kelana Jaya LRT Line, Malaysia

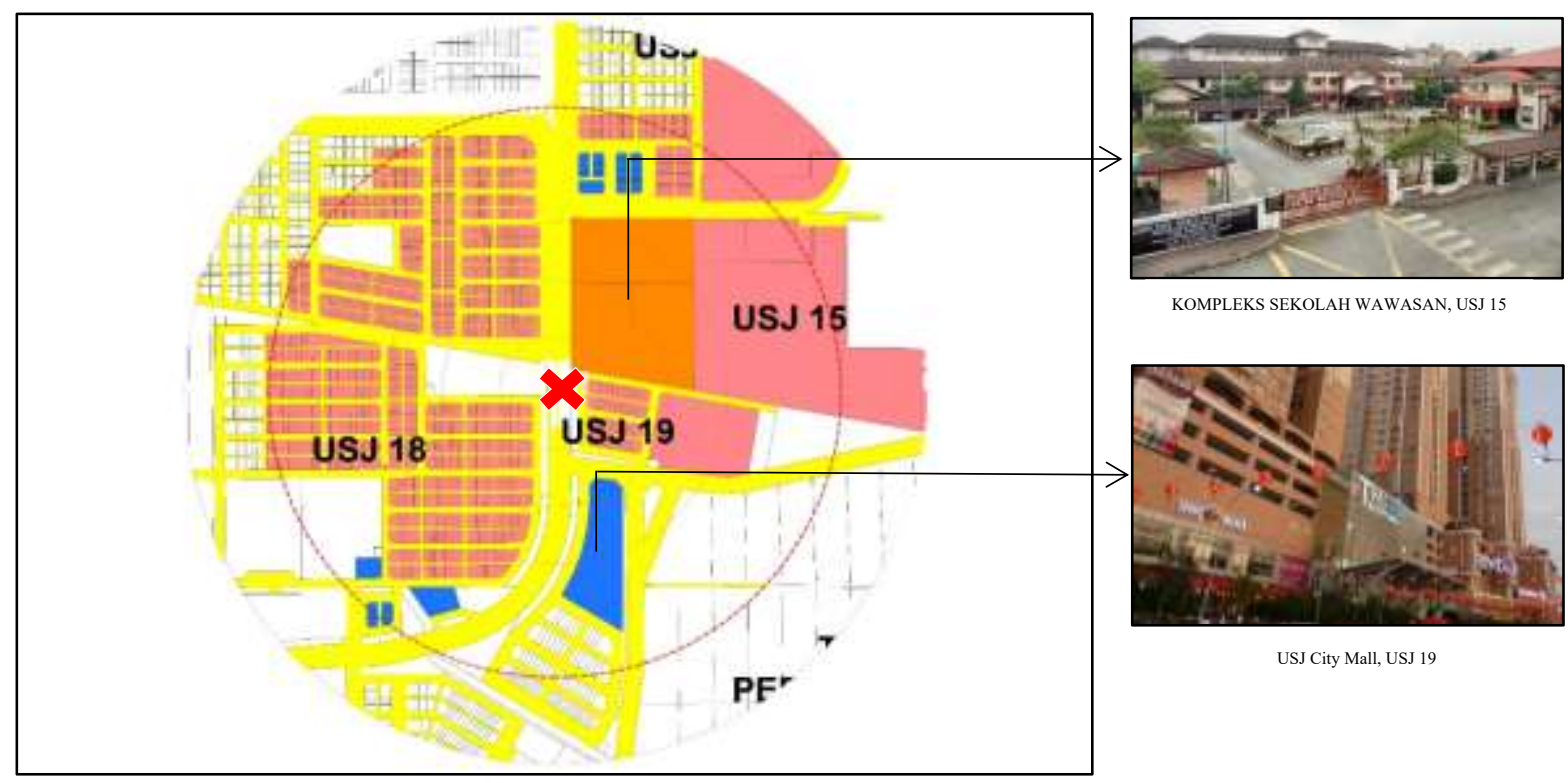

Figure 9: Land use distribution at Wawasan LRT station (high LUPTAI, low ridership)

The reverse situation was found at USJ 7 station. Despite having a lower LUPTAI figure, it had the highest ridership number which was four times that of the Wawasan station. The reason was that it had a good mixture of commercial and residential land uses within the 500 metres of radius. The commercial development, such as USJ Summit Mall and Mydin Hypermarket, as well as the multi-storey apartments, such as the Subang Perdana Goodyear provided a strong base of ridership to the station. USJ Summit Mall and Mydin Hypermarket with the surrounding commercial areas, were the main commercial areas in Subang Jaya. In addition, the provision of park and ride parking facilities in the station area attracted people who lived farther from the station to use the LRT service. 


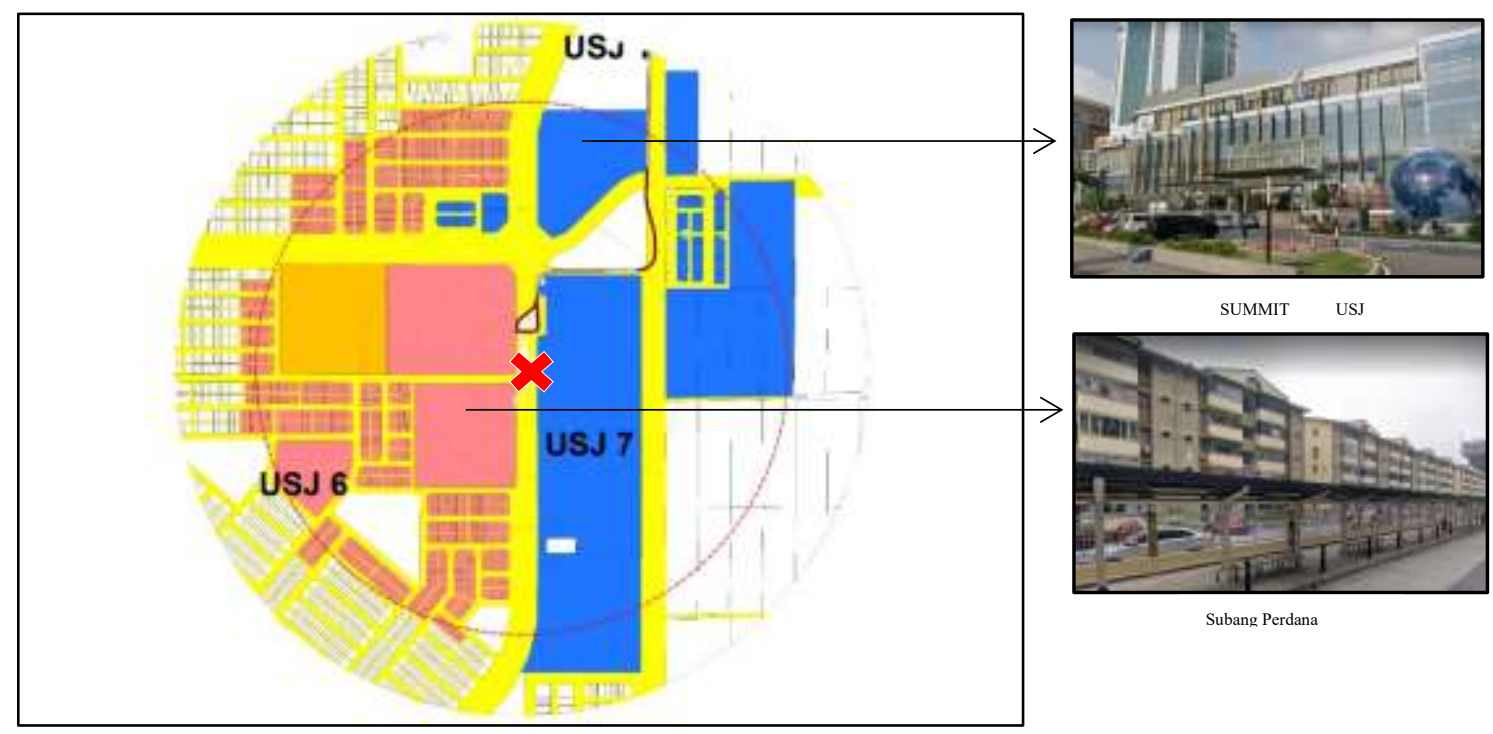

Figure 10: Land use distribution at USJ7 LRT station (low LUPTAI, high ridership)

\section{SUMMARY AND CONCLUDING REMARKS}

The study found that there was no conclusive relationship between LUPTAI and ridership for the ten LRT stations selected. This was perhaps due to the fact that LUPTAI figures for all stations did not differ much since they were based on the distance of urban land use - commercial, residential, and public facilities - from the LRT stations. Since all the ten stations are located in urban areas of Petaling Jaya and Subang Jaya and thus have been developed with the said urban land uses, not much variations in LUPTAI figures were found among them. As a result, the simple LUPTAI method of measuring distance of urban land uses from LRT stations in this study was probably more appropriate in a comparative analysis of LRT stations in more established areas (with commercial and residential areas) and newer areas which tended to have more undeveloped lands.

A modified LUPTAI index that took into account the other factors than the distance of urban land uses from the LRT stations would most likely provide a better reflection of urban development around the stations. These factors which included the type and mixture of developments on land, the density for residential areas and intensity of commercial development would provide a better reflection on intensity of urban development around stations. This index would perhaps have a strong correlation with the ridership of the stations as expected based on the TOD theory. 
Abdullah, J., Abdul Rashid, K., Baharom Shah M.I., Oliver Ling Hoon Leh, Abdul Majid, R., Ngah, R.

Land Use Development and Ridership at Kelana Jaya LRT Line, Malaysia

Regardless of the lack of relationship due to the simplified LUPTAI calculations, it was observed that areas with commercial or mixture of commercial and residential uses seemed to have high ridership figures. In addition, there seemed to be a relationship between the higher intensity of use, such as high rise residential or high plot ratio for commercial building with high ridership figures as exhibited by USJ7 station. This augured well with the theory of TOD which advocated for high density and intensity of use for areas within the vicinity of TOD stations.

\section{ACKNOWLEDGEMENT}

The authors would like to thank UiTM for providing MITRA grant for this research. Much appreciation also goes to Prasarana Malaysia for providing the ridership data and allowing interview sessions to be conducted at the ten selected stations.

\section{REFERENCES}

Arina Rahmat, Intan Rohani Endot, Zakaria Ahmad, Zaharah Ishak, \& Che Khairil Izam Ibrahim (2016). Development of Transit Oriented Development (TOD) model for Malaysia. Journal of Built Environment, Technology and Engineering, 36-47.

Al-Sahili, Khaled, A., \& Sadeq, A. H. (2003). Ridership demand analysis for Palestinian intercity public transport. Journal of Public Transportation, 6(2), 19-35.

Buang, S. (2018). Embracing Transit-Oriented Development. Retrieved December 5, 2018 from https://www.nst.com.my/opinion/ columnists/2018/04/352335/embracing-transit-oriented-development.

Bertolaccini, K., Hickman, M., \& Pyrohova, S. (2018). Incorporating reliability into Queensland's LUPTAI accessibility model. CASPT 2018 Extended Abstract, 1-5.

Chan, S., \& Miranda-Moreno, L. (2013). A station-level ridership model for the metro network in Montreal, Quebec. Canadian Journal of Civil Engineering, 40(3), 254262.

Choi, J., Lee, Y.J., Kim, T., \& Sohn, K., (2012). An analysis of metro ridership at the station to station level in Seoul. Transportation, 39(3), 705-722.

Chu, X. (2004). Ridership Models at the Stop Level. Report No. BC137-31 prepared by National Center for Transit Research for Florida Department of Transportation.

Ding, C., Liu, C., Zhang, Y., Yang, J., \& Wang, Y., (2017). Investigating the impacts of built environment on vehicle miles traveled and energy consumption: differences between commuting and non-commuting trips. Cities, 68, 25-36.

Gomez, C., Mashitah Omar, \& Nallusamy, R. (2019), A study on the benefits of Transit Oriented Development in Malaysia and incorporation of those benefits in planning. MATEC Web of Conferences, 266, 06016.

Guowei, L. L. B., \& Pfeffer, K. (2020), How does transit-oriented development contribute to station area accessibility? A study in Beijing. International journal of Sustainable Transportation, 14(7), 533-543. 
Handy, S., \& Clifton, K. (2001). Evaluating neighbourhood accessibility. Journal of Transportation and Statistics, 4(2/3), 67-78.

Hu, L., Sun, T., \& Wang, L. (2018). Evolving urban spatial structure and commuting patterns: a case study of Beijing, China. Transport. Res. Part D: Transport. Environment. 59, 11-22.

Litman, T. (2016). The Hidden Traffic Safety Solution. Public Transportation. Public transportation can help save lives by reducing traffic crashes, American Public Transportation Association, Washington D.C.

Litman, T. (2018). Evaluating public transit benefits and costs - best practices guidebook. Canada: Victoria Transport Policy Institute.

Liu, S., Yao, E., \& Li, B, (2018). Evolving urban spatial structure and commuting patterns: a case study of Beijing, China. Transport. Res. Part D: Transport. Environment. 59, 11-22.

Lund, H. M., Cervero, R., \& Willson, R. W. (2004). Travel Characteristics of TransitOriented Development in California. California Department of Transportation, Sacramento, CA: California Department of Transportation.

Mohammed Ali Berawi Gunawan Saroji, Fuad Adrian Iskandar, Bernard Elpetino Ibrahim, Perdana Miraj, \& Mustika Sari (2020) Optimizing land use allocation of Transit-Oriented Development (TOD) to generate maximum ridership, Sustainability, 12, 3798.

Pitot, M., Tan, Y., Sipe, N., \& Evans, R. (2006). Land Use \& Public Transport Accessibility Index (LUPTAI) tool - the development and pilot application of LUPTAI for the Gold Coast, 2006 Planning and Transport Research Centre (PATREC), Proceedings of the $29^{\text {th }}$ Australian Transport Research Forum (ATRF), 1-18.

Prasarana Malaysia (2020). Ridership data of LRT Kelana Jaya Line, Unpublished report.

Singh, A. C., Astroza, S., Garikapati, V. M., Pendyala, R. M., Bhat, C. R., Mokhtarian, P. L. (2018). Quantifying the relative contribution of factors to household vehicle miles of travel. Transp. Res. Part D: Transp. Environ. 63, 23-36.

Sohoni, A. V., Thomas, M., Rao, K. K. (2016), Application of the concept of transitoriented development to a suburban neighbourhood. Transportation Research Procedia, 25, 3220-3232.

Suzuki, H., Murakumi, J., Hong, Y. H., Tamayose, B. (2015). Financing Transit-Oriented Development with Land Values, Adapting Land Value Capture in Developing Countries. The world banks. Washington, DC, USA: International Bank for Reconstruction and Development.

Tay, H. (2012). Cycling infrastructure as a first mile solution for mass transit access in Singapore: A study of MRT ridership in Singapore towns. (Unpublished Master's thesis.) Cambridge, MA: Department of Urban Studies and Planning, Massachusetts Institute of Technology.

Tan, Y., Sipe, N., \& Evans, R. (2006), Land Use \& Public Transport Accessibility Index (LUPTAI) tool - the development and pilot application of LUPTAI for the Gold Coast, Proceedings of the 29th Australian Transport Research Forum (ATRF), 118.

Tan, Y., Sipe, N., Evans, R., \& Pitot, M. (2007), A GIS-based land use and public transport accessibility indexing model. Australian Planner, 44(3), 30-37. 
Abdullah, J., Abdul Rashid, K., Baharom Shah M.I., Oliver Ling Hoon Leh, Abdul Majid, R., Ngah, R. Land Use Development and Ridership at Kelana Jaya LRT Line, Malaysia

Wu, B., \& Hine, J. (2003). A PTAL approach to measuring changes in bus service accessibility. Transport Policy, 10, 307-320.

Yuxin, H., Yang, Z., \& Kwok, L. T. (2018). An Analysis of Factors Influencing Metro Station Ridership: Insights from Taipei Metro, Proceedings of the 21st International Conference on Intelligent Transportation Systems (ITSC), 15981603.

Received: $15^{\text {th }}$ May 2020. Accepted: $1^{\text {st }}$ Sept 2020 